\title{
Próteinútfellingar í lungnablöðrum meðhöndlaðar með lungnaskoli
}

Ragnheiður M. Jóhannesdóttir ${ }^{1}$ leknir, Steinn Jónsson ${ }^{2,5}$ læknir, Felix Valsson ${ }^{3,5}$ læknir, Hrönn Harðardóttir ${ }^{2,5}$ læknir, Ólöf R. Ámundadóttir²,5 sjúkrapjálfari, Eypór Björnsson ${ }^{2,5}$ læknir, Sigfús Nikulásson ${ }^{4}$ læknir, Tómas Guðbjartsson ${ }^{1,5}$ læknir

\section{ÁGRIP}

Próteinútfellingar í lungnablöðrum er sjaldgæfur lungnasjúkdómur af ópekktum orsökum par sem lípóprótein sem líkist lungnablöðruseyti safnast fyrir í lungum. Hér er greint frá ungum karlmanni sem greindist með sjúkdóminn eftir nokkurra mánaða sögu um versnandi mæði, hitavellu, pyngdartap og truflun á súrefnisupptöku. Lungnamynd sýndi dreifðar péttingar í báđum lungum. Greiningin fékkst staðfest með vefjasýnatöku við berkjuspeglun. Vegna versnandi einkenna var ákveðið að skola bæði lungu með saltvatni í svæfingu. Tæpum tveimur árum síðar er sjúklingur nánast einkennalaus og öndunarmælingar sýna góða lungnastarfsemi.
${ }^{1}$ Hjarta- og ungnaskurðdeild, 2lungnadeild, ${ }^{3}$ svæfinga- og gjörgæsludeild, ${ }^{4}$ meinafræðid Landspítala, ${ }^{5}$ æknadeild HI.

Fyrirspurnir: Tómas Guðbjartsson tomasgud@landspitali.is

Greinin bars 13. maí 2014 , sampykkt til birtingar 8. september 2014.

\section{Inngangur}

Próteinútfellingar í lungnablöðrum (pulmonary alveolar proteinosis, PAP) eru oftast af ópekktum orsökum en meingerð sjúkdómsins er rakin til skertrar átfrumuvirkni í lungnablöðrum sem veldur pví að lípóprótein sem líkjast lungnablöðruseyti safnast fyrir í lungnablöðrum og smærri loftvegum. ${ }^{1}$ Fyrsta tilfellinu var lýst af Rosen og félögum árið 1958. ${ }^{1,2}$ Algengustu einkenni útfellinganna eru frá lungum, aðallega mæði og hósti. Á lungnamynd og tölvusneiðmyndum sjást dreifðar péttingar í báðum lungum en greiningin er staðfest með sýnatöku við berkjuspeglun, annaðhvort með vefjasýni eða berkjuskoli og í einstaka tilfellum með opinni sýnatöku. Hér er lýst tilfelli par sem lungnaskolun í svæfingu reyndist mjög árangursrík. Um er að ræða fyrsta tilfellið sem lýst hefur verið hér á landi.

\section{Tilfelli}

Rúmlega prítugur stórreykingamaður leitaði á bráðamóttöku Landspítala eftir að hafa verið með vaxandi mæði, hósta, uppgang, hitavellu og megrun í fjóra mánuði. Við skoðun var hann hitalaus, andstuttur í hvíld og með brak yfir báðum lungum við hlustun. Súrefnismettun var 94\% í hvíld á andrúmslofti og öndunartíðni 20/mín. Frekari rannsóknir sýndu að hvít blóðkorn voru 5,7×109 (eðlilegt gildi 4,0-10,5×10) og CRP $14 \mathrm{mg} / \mathrm{ml}$ (eðlilegt gildi <6 mg/ml). Röntgenmynd af lungum sýndi dreifðar netlaga (reticular) og hnökróttar (nodular) íferðir og voru pær meira áberandi í vinstra lunga (mynd 1a). Á tölvusneiðmyndum sáust hélubreytingar (ground glass) á víð og dreif í báðum lungum, mest í neðra blaði vinstra lunga (mynd 1b). Mantoux-próf var neikvætt en einnig bakteríu- og svepparæktanir frá hráka. Gerð var berkjuspeglun sem sýndi hvítleitt slím í loftvegum. Í spegluninni var einnig gert berkjuskol (bronchoalveolar lavage) og fékkst út ljósleitur gruggugur vökvi. Pá voru tekin vefjasýni í gegnum berkjuvegg með aðstoð skyggningar. Ræktanir á berkjuskoli voru neikvæðar og engar illkynja frumur sáust við frumuskoðun. Hins vegar sýndi vefjasýni úr spegluninni dæmigert útlit fyrir próteinútfellingar í lungnablöðrum (mynd 2).

Mæðin versnaði og fjórum mánuðum síðar átti sjúklingur í erfiðleikum með minnstu hreyfingar. Auk pess kvartaði hann um brjóstverki, hitavellu og gulleitt slím frá öndunarvegum. Hann var pví lagður inn á lungnadeild Landspítala. Næstu daga versnuðu loftskipti og mældist súrefnismettun 88-90\% með 151 af súrefni á maska og öndunartíðni var 30-40/mín. Ákveðið var að gera lungnaskolun í svæfingu og var hann fluttur á

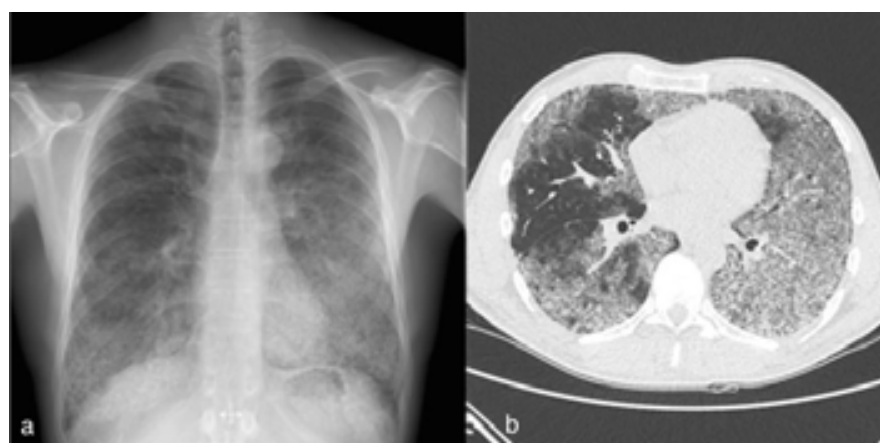

Mynd 1. a) Röntgenmynd af lungum við greiningu sem sýnir útbreiddar péttingar í bádum lungum. b) Tölvusneiðmynd af lungum við greiningu. Almennar hélubreytingar sjást í báðum lungum en eru mest áberandi i neðra vinstra lungnablaði. 


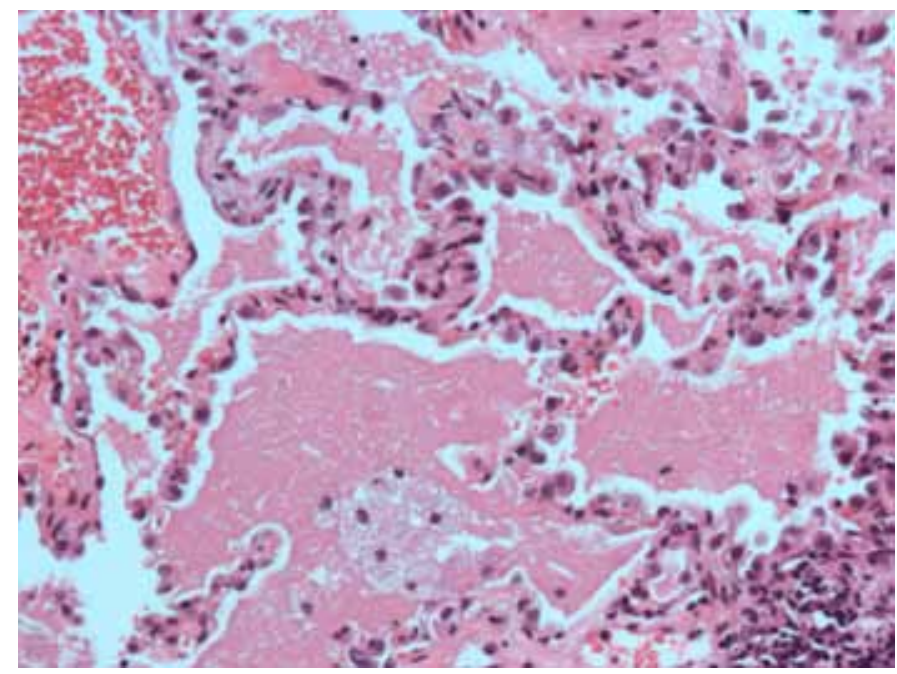

Mynd 2. Smásjárskoðun á vefjasýni sem tekið var með berkjuspeglun. $40 x$ stækkun HE litun. Lungnavefur með bleiku, fínkornóttu efni i holrúmum lungnablaðra en í tengslum við efnið er hópur átfruma.

brjóstholsskurðdeild. Par voru honum gefnir bólgueyðandi sterar (prednisólon, $25 \mathrm{mg}$ á dag) og azithromycin í töfluformi.

Lungnaskolun var framkvæmd á skurðstofu í hefðbundinni svæfingu. Ákveðið var að skola vinstra lungað fyrst, enda íferðir mestar par. Sjúklingur var barkapræddur með tvöfaldri barkarennu (double-lumen endotracheal tube) og lá endinn út í vinstri höfuðberkju. Lega berkjurennunnar var staðfest með lungnahlustun og berkjuspeglun. Sjúklingnum var síðan komið fyrir í 90 gráðu hliðarlegu með vinstri hlið upp og loftflæði til vinstra lunga stöðvað (mynd 3). Hægra lungað var síðan blásið í 15 mínútur með $100 \%$ súrefni. Hækkað var undir höfði sjúklings og 11 af $37^{\circ} \mathrm{C}$ heitu saltvatni $(0,9 \%)$ látið renna inn í vinstra lunga. Eftir innhellinguna bankaði sjúkrapjálfari vinstri brjóstkassa í um 5 mínútur og var skurðarborði vaggað svo skolvöki dreifðist um lungað. Til að tæma vökvann úr lunganu var höfuð sjúklings lækkað og vökvanum safnað í sýnaglös. Petta ferli var endurtekið 15 sinnum á vinstra lunga með samtals $15 \mathrm{l}$ af saltvatni. Í fyrstu var skolvökvinn mjög gruggugu en lýstist pegar á leið (mynd 4). Eftir skolunina var gerð berkjuspeglun og pannig reynt að ná öllum vökva úr lunganu. Sjúklingurinn var vakinn á skurðstofu og fluttur á gjörgæsludeild par sem hann dvaldi í sólarhring til eftirlits. Súrefnismettun fyrir skolun var 95\% á 100\% súrefni til hægra lunga og héldust bæði blóðprýstingur og önnur lífsmörk stöðug. Klukkutíma eftir skolun mældist súrefnismettun á gjörgæslu 100\% með 151 af súrefni í maska og var öndunartíðni pá 40/mín.

Fjórum dögum síðar var sjúklingurinn færður aftur á skurðstofu og svæfður með hægri hlið upp. Súrefnismettun mældist pá 95\% á 51 af súrefni. Eftir að hægra lunga hafði verið skolað með 51 af saltvatni varð að hætta skoluninni par sem skolvökvinn skilaði sér ekki nógu vel til baka úr lunganu. Var ástæðan talin vera leki á saltvatni út í vinstra lunga meðfram belg á berkjurennunni. Hann var pví færður sofandi á gjörgæsludeild í öndunarvél en jafnaði sig fljótt. Skolunin var síðan endurtekin 8 dögum síðar á sambærilegan hátt. Súrefnismettun fyrir pá skolun mældist 95\% á 100\% af súrefni. Hægra lungað var skolað með samtals 181 af saltvatni, 1 li senn og brjóstholsbanki beitt á milli skolana. Skolunin gekk að óskum og sjúklingurinn var vakinn á skurðstofu. Tveimur dögum síðar útskrifaðist hann heim til sín við góða líðan. Röntgenmynd af lungum sem tekin var við útskrift sýndi minni íferðir (mynd 5) og mældist súrefnismettun $90 \%$ án súrefnis og öndunartíðni 14/mín.

Við eftirlit mánuði síðar mældist súrefnismettun 95\% án viðbótarsúrefnis og öndunarmælingar sýndu miðlungs herpu, með FEV1 2,45 L og FEV1/FVC hlutfall sem er 73\% af spáðu gildi. Næstum tveimur árum frá greiningu fann sjúklingur enn fyrir mæði við áreynslu en er einkennalaus í hvíld. Öndunarmælingar voru áfram batnandi og mældust innan eðlilegra marka, með FEV1/ FVC hlutfall 91\% af spáðu. Einnig sáust minni péttingar á röntgenmyndum af lungum enda pótt vægar íferðir væru enn til staðar (mynd 5).
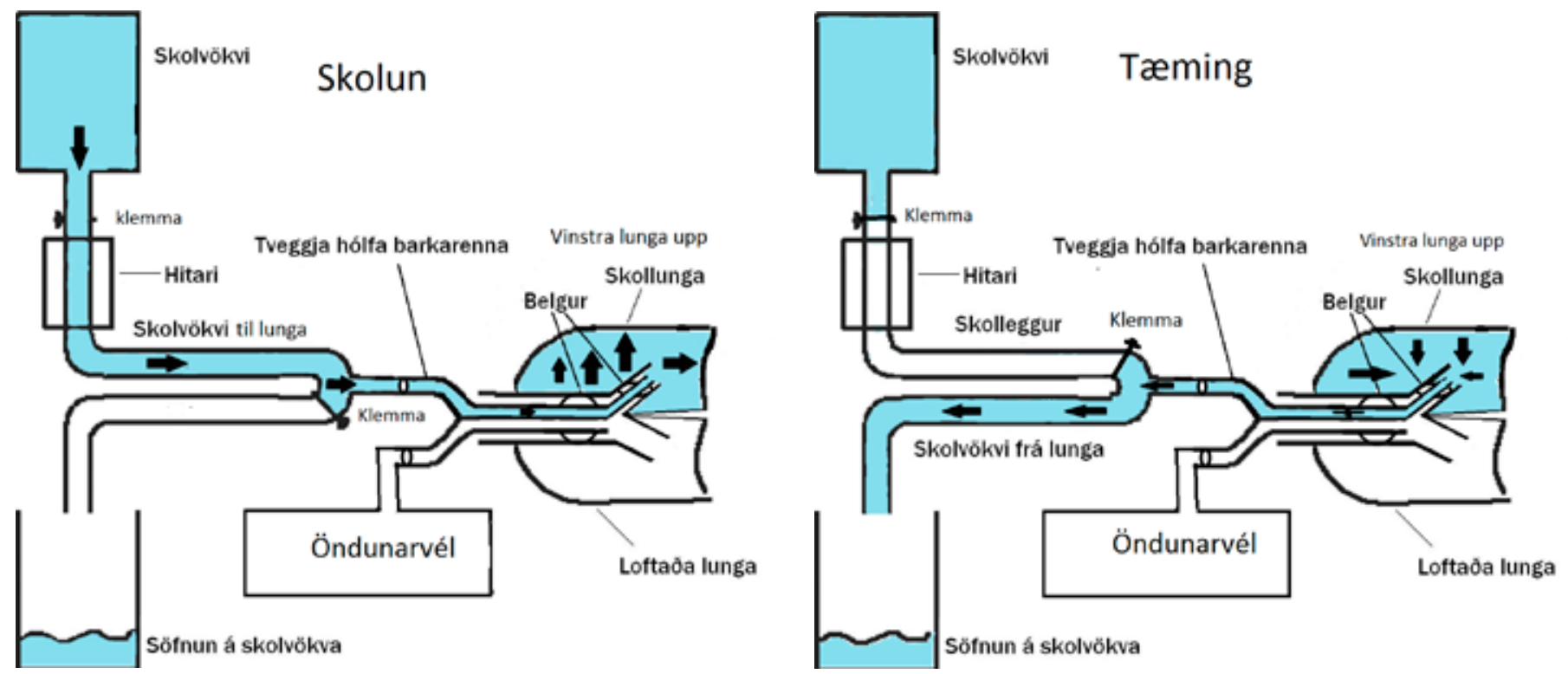

Mynd 3. Lungnaskolun. Skolvökvi er hengdur upp og látinn renna í gegnum hitara. Lás er settur milli vökva og hitara svo unnt sé að stjórna flæði og magni sem fer inn ílungað. Aðeins eitt lunga sér um loftskipti og er tengt við öndunarvél á meðan hitt lungað er skolað. Lás er á milli affallsrásar og vökvasafnara til að geta tímasett tæmingu skolvökva úr lunga. Myndin er eftir Felix Valsson, breytt og staðfærð úr heimild nr. 5. 


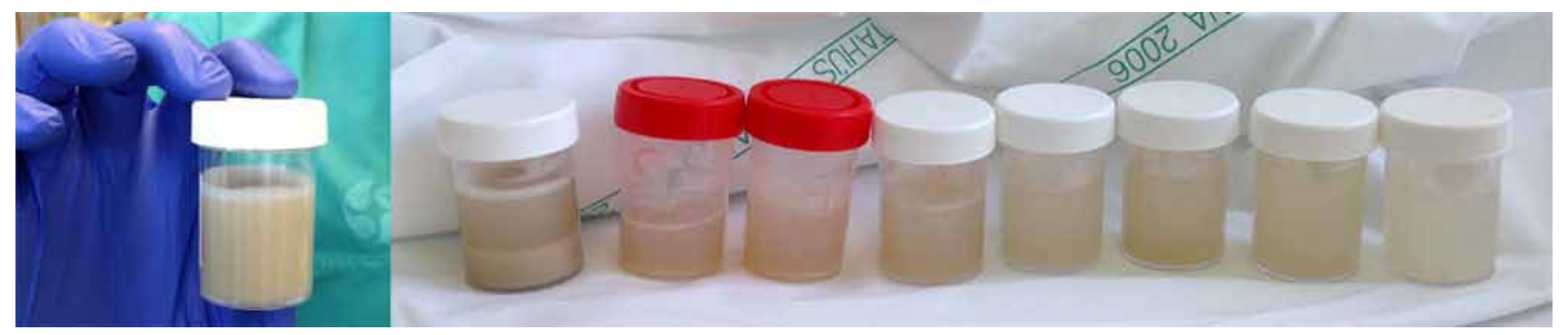

Mynd 4. Sýni úr frá skolvökva frá vinstra lunga, sem lýsist og pynnist eftir pví sem lungað er skolað með meira saltvatni.

\section{Umræða}

Lungnaskolun getur verið árangursrík meðferð við próteinútfellingar í lungnablöðrum, eins og okkar tilfelli sýnir. Einkenni löguðust umtalsvert og tæpum tveimur árum frá skolun hefur ekki borið á endurkomu sjúkdómsins og öndunarmælingar eru innan eðlilegra marka. Í flestum tilvikum polist lungnaskolun vel. Pó kemur fyrir að hætta purfi skolun ef súrefnismettun verður of lág. Í okkar tilfelli purfti að hætta lungnaskolun á hægra lunga vegna leka yfir í vinstra lungað. Slíkur leki getur skapað hættulegt ástand pví pá berst vökvi út í pað lunga sem sér um loftskipti pegar skolunin fer fram. Af pessum sökum er yfirleitt aðeins annað lungað skolað í einu enda pótt einnig hafi verið reynt að skola bæði lungu í sömu svæfingu með góðum árangri. ${ }^{3}$ Aðrir fylgikvillar lungnaskolunar eru loftbrjóst, vatnsloftbrjóst (hydropneumothorax) og fleiðruvökvi. ${ }^{4,5}$

Lungnaskolun við próteinútfellingar í lungnablöðrum var fyrst lýst árið 1965 af Ramirez og félögum sem höfðu beitt meðferðinni við 6 sjúklinga með góðum árangri. ${ }^{6}$ Síðan pá hefur lungnaskolun verið fyrsta meðferð við próteinútfellingum í lungnablöðrum. Meðferðinni er pó aðeins beitt pegar mikil einkenni eru til staðar, ${ }^{1,5}$ eins og átti við í okkar tilfelli. Samkvæmt rannsókn Shah og félaga læknast $60 \%$ sjúklinga eftir tvær skolanir en 5 árum eftir greiningu hafa tveir priðju sjúklinga gengist undir lungnaskolun og 80\% hafa hlotið bata. Í áðurnefndri rannsókn purftu 15\% sjúklinga endurtekna skolun á hálfs árs fresti og 10\% sjúklinga svöruðu meðferðinni ekki. Loks er talið að um fjórðungur sjúklinga læknist án meðferðar ${ }^{7}$ og 10-15\% deyi úr sjúkdómnum. ${ }^{8}$

Próteinútfellingar í lungnablöðrum er sjaldgæfur sjúkdómur en talið er að nýgengi sjúkdómsins sé á bilinu 0,36-0,49/milljón einstaklinga, enda pótt góðar faraldsfræðilegar rannsóknir vanti. ${ }^{1}$ Flestir sjúklingar eru í kringum fertugt við greiningu og helmingi fleiri karlar greinast með sjúkdóminn en konur. ${ }^{1}$ Að pví best er vitað er petta tilfelli pað fyrsta sem lýst hefur verið hér á landi.

Orsök próteinútfellinga í lungnablöðrum er ekki pekkt í 90\% tilvika en meingerð sjúkdómsins er rakin til Ig-G mótefna sem beinast gegn granulocyte macrophage colony stimulating factor (GMCSF). Afleiðingin er skert starfsemi átfrumna í lungnablöðrum en pær viðhalda meðal annars jafnvægi á framleiðslu og niðurbroti lungnablöðruseytis. ${ }^{9}$

Sjúkdómurinn getur verið meðfæddur og tengist pá galla á genum sem kóða fyrir viðtökum GM-CSF og hefur pannig áhrif á bindingu viðtaka og boðferli. ${ }^{10}$ Aðrir sjúkdómar sem geta tengst próteinútfellingum í lungnablöðrum eru krabbamein ýmiss konar, og geta ekki síst komið fram hjá sjúklingum með illkynja blóðsjúkdóma sem purfa beinmergsígræðslu. Einnig hafa sýkingar verið tengdar við próteinútfellingar í lungnablöðrum og má par nefna veirusýkingar og sýkingar með nocardia og pneumocystitis. Mikil rykmengun á vinnustað er einnig talin geta stuðlað að próteinútfellingum í lungnablöðrum. ${ }^{1,8}$

Greiningin er yfirleitt staðfest með vefjasýni frá lunga, sem má nálgast með berkjuspeglun eða opinni sýnatöku. Útlit er dæmigert í ljóssmásjá, óháð orsök. Par sést að lungnablöðrur og smæstu berkjur eru fullar af periodic acid schiff (PAS) jákvæðu frumusnauðu seyti. Uppbygging lungans er varðveitt og ekki merki um bólgu eða ífarandi vöxt. ${ }^{5}$ Berkjuskol er einnig jákvætt í PAS-litun og við smásjárskoðun sjást stórar froðukenndar átfrumur. Í skolinu geta einnig fundist mótefni gegn GM-CSF. ${ }^{1}$

Myndgreiningarrannsóknir eru ekki jafn afgerandi og vefjasýni eða berkjuskol. Oftast sýna pær samhverfar péttingar aðlægt lungnaportum sem geta líkst leðurblökuvængjum (bat-wing sign). Á tölvusneiðmyndum sjást oft hélubreytingar og pykknun á mótum lungnablöðrunga (interlobular septum). ${ }^{1}$

Öndunarmælingar sýna langoftast herpumynstur. Pví miður var ekki gerð öndunarmæling fyrir lungnaskolun hjá okkar sjúklingi en öndunarmæling eftir skolun sýndi miðlungs herpu. Tveimur árum síðar voru öndunarmælingar innan eðlilegra marka.

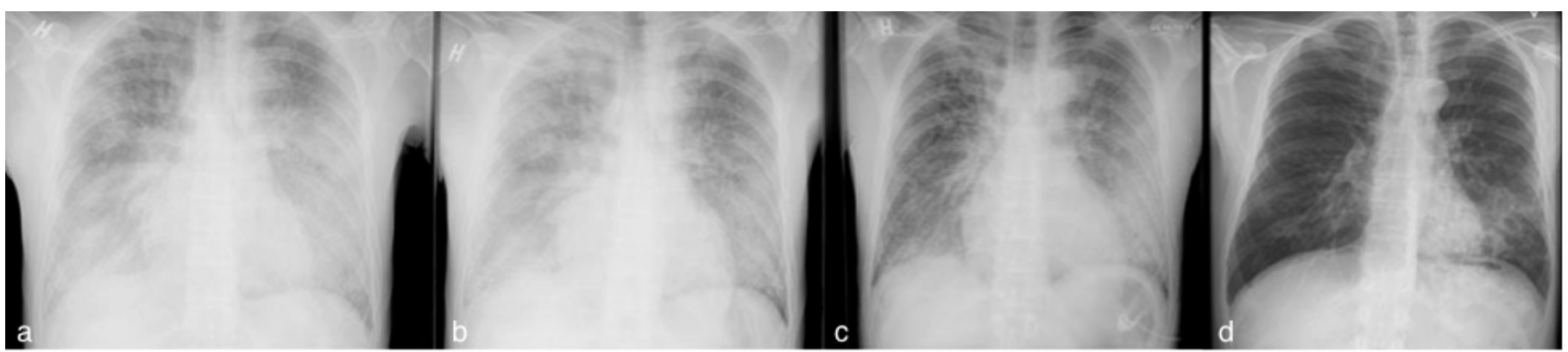

Mynd 5. Röntgenmynd af lungum, a) fyrir lungnaskolun, b) eftir skolun á vinstra lunga, c) eftir skolun á bádum lungum, og d) 8 mánuðum eftir skolun á bádum lungum. 
Á undanförnum árum hafa komið fram nýir valkostir í meðferð sem hægt er að grípa til pegar lungnaskolun skilar ekki tilætluðum árangri. Má par nefna meðferð með GM-CSF sem gefin er undir húð og svara allt að tveir priðju sjúklinga pessari meðferð. Einnig er hægt að gefa GM-CSF í innöndunarúða. ${ }^{1}$ Meðferð með rituximab, sem er einstofna mótefni sem fækkar plasmafrumum og um leið myndun á GM-CSF sjálfs-mótefnum, lofar góðu hjá pessum sjúklingum. ${ }^{1}$

Hér hefur verið lýst tilfelli af próteinútfellingum í lungnablöðrum par sem lungnaskolun var beitt með góðum árangri. Tveimur árum síðar hefur sjúklingurinn náð góðum bata og ekki borið á endurkomu sjúkdómsins. Öndunarmælingar eru nánast eðlilegar og íferðir á lungnamynd ekki lengur til staðar. Vert er að hafa próteinútfellingar í huga hjá einstaklingum með mæði og dreifðar íferðir í lungum.

Pakkir fær Maríanna Garðarsdóttir röntgenlæknir fyrir aðstoð við gerð mynda.

\section{Heimildir}

1. Leth S, Bendstrup E, Vestertgaard $\mathrm{H}$, Hilberg $\mathrm{O}$. Autoimmune pulmonary alveolar proteinosis: Treatment options in year 2013. Respirology 2013; 18: 82-91.

2. Rosen SH, Castelman B, Liebow AA. Pulmonary alveolar proteinosis. N Eng J Med 1958; 258: 1123-42.

3. Beccaria M, Luisetta M, Rodi G, Corsico A, Zoia MC Colato $\mathrm{S}$, et al. Long term durable benefit after whole lung lavage in pulmonary alveolar proteinosis. Eur Respir J 2004; 23: 526-31.

4. Vanderhelst E, Hanon S, Verbanck S, Schuermans D, Wissing $\mathrm{K}$, Bonella $\mathrm{F}$ et al. Whole-Lung Lavage: A successful Treatment for Restoring Acinar Ventilation Distribution in Primary Acquired Pulmonary Alveolar Proteinosis. Respiration 2012; 84: 70-4.
5. Gaetane Michaud, MD, Chakravarthy Reddy, MD, Armin Ernst MD. Whole Lung Lavage for Pulmonary alveolar Proteinosis. Chest 2009; 136: 1678-81.

6. Ramirez RJ, Kieffer RF, Ball WC. Bronchopulmonary lavage in man. Ann Intern Med 1965; 63: 819-28.

7. Shah PL, Hansell D, Lawson PR, Reid KB, Morgan C. Pulmonary alveolar proteinosis: clinical aspects and current concepts on pathogenesis. Chest 2004; 125: 2351-6. 8. Seymour JF, Presneill JJ. Pumlonary alveolar proteinosis, progress in the first 44 years. Am J Respir Crit Care Med 2002; 166: 215-35.
9. Tanaka N, Watanabe J, Kitamura T, Yamada Y, Kanegasaki $S$, Nakata K. Lungs of patients with idiopathic pulmonary alveolar proteinosis express a factor which neutralizes granulocyte-macrophage colony stimulating factor. FEBS Lett 1999; 442: 246-50.

10. Ben-Dov I, Segel MJ. Autoimmnue pulmonary alveolar proteinosis: clinical course and diagnostic criteria. Autoimmune Rev 2014, dx.doi.org/10.1016/j.autrev.2014.01.046

\section{ENGLISH SUMMARY}

\section{Pulmonary alveolar proteinosis - a case report}

Ragnheidur M. Johannesdottir ${ }^{1}$, Steinn Jonsson ${ }^{2,5}$, Felix Valsson ${ }^{3,5}$, Hronn Hardardottir ${ }^{2,5}$, Olof R. Amundadottir ${ }^{2,5}$, Eythor Bjornsson ${ }^{2,5}$, Sigfus Nikulasson $^{4,5}$ Tomas Gudbjartsson ${ }^{1,5}$

Pulmonary alveolar proteinosis (PAP) is a rare lung disease of unknown origin, where an amorphous lipoprotein material accumulates in the alveoli of the lungs. We describe a young male with a four month history of progressive dyspnea, low grade fever, hypoxemia and weight loss. Chest X-ray showed diffuse interstitial and alveolar infiltrates in both lungs. The diagnosis of PAP was confirmed with trans-bronchial lung biopsy. Because of a deteriorating clinical course a whole lung lavage was performed. Under general anesthesia, both lungs were lavaged with warm saline in two different sessions with good results. Two years later the patient is almost free of symptoms and lung function has markedly improved.

Departments of ${ }^{1}$ Cardiothoracic Surgery, ${ }^{2}$ Pulmonology, ${ }^{3}$ Anesthesiology \& Intensive care and ${ }^{4}$ Pathology Landspitali University Hospital, ${ }^{5}$ Faculty of Medicine, University of Iceland.

Key words: Pulmonary alveolar proteinosis, whole lung lavage, dyspnea, bronchoscopy, case report.

Correspondence: Tómas Guðbjartsson, tomasgud@landspitali.is 